\title{
Comparison of tetracycline and minocycline in the treatment of non-gonococcal urethritis
}

\author{
J D ORIEL* AND G L RIDGWAYT \\ From the Departments of ${ }^{*}$ Genitourinary Medicine and + Clinical Microbiology, University College \\ Hospital, London
}

SUMMARY The activity of tetracycline hydrochloride and minocycline hydrochloride was compared against 12 strains of Chlamydia trachomatis and Ureaplasma urealyticum; minocycline was more active in vitro against both organisms. A group of 145 men with non-gonococcal urethritis was treated for one week with either tetracycline hydrochloride $500 \mathrm{mg}$ six hourly or minocycline $50 \mathrm{mg}$ twice daily. The clinical results obtained were similar: 61 of $77(79 \%)$ men treated with tetracycline and 53 of $68(78 \%)$ men treated with minocycline were free from urethritis one to two weeks after completing treatment. Both antibiotics were clinically effective against $C$ trachomatis, but activity against $U$ urealyticum was less consistent. Side effects were noted in $14(18 \%)$ men treated with tetracycline and eight $(12 \%)$ men treated with minocycline; they were predominantly gastrointestinal.

\section{Introduction}

Chlamydia trachomatis is a major cause of nongonococcal urethritis (NGU), ${ }^{1}$ and although the role of Ureaplasma urealyticum is less clear it is believed to cause some cases. ${ }^{2}$ Between $25 \%$ and $50 \%$ of cases of NGU are of unknown aetiology. The tetracyclines are in general use for the treatment of NGU. $C$ trachomatis is consistently sensitive, ${ }^{3}$ but between $6 \%$ and $10 \%$ of strains of $U$ urealyticum are resistant, and these may cause some treatment failures. ${ }^{4}$ The choice of tetracycline for bacterial treatment is not unimportant; for example, tetracycline-resistant strains of Haemophilus influenzae are inhibited by minocycline, 5 and anaerobic bacteria are more responsive to minocycline than to tetracycline or doxycycline. ${ }^{6}$ The action of tetracyclines against $C$ trachomatis may be studied in cell culture. If tetracyclines are added one hour after $C$ trachomatis there is little difference between the effect of tetracycline, minocycline, or doxycycline, but if they are added 48 hours after inoculation minocycline and doxycycline are much more active than tetracycline. ${ }^{3}$ The results of the action of tetracycline against $U$ urealyticum in vitro are conflicting and seem to depend on the laboratory

Address for reprints: Dr J D Oriel, Department of Genitourinary Medicine, University College Hospital, Grafton Way, London WC1E 6AU

Accepted for publication 7 February 1983 procedure used, ${ }^{78}$ but tetracycline-resistant strains also appear to be resistant to minocycline. ${ }^{9}$

In this study we first compared the activity of tetracycline and minocycline against 12 fresh isolates of $C$ trachomatis and $U$ urealyticum and then treated a group of men with NGU with either antibiotic for one week and compared the clinical and microbiological results.

\section{Patients and methods}

The isolates of $C$ trachomatis and $U$ urealyticum for determination of minimum inhibitory concentrations (MICs) were obtained from unselected men with NGU. The clinical study was performed in the department of genitourinary medicine, University College Hospital, London, between September 1979 and March 1980. Men were included if $(a)$ they were symptomatic; (b) they showed $\geqslant 10$ polymorphonuclear leucocytes (PMNL) per high power field $(\times 100$ objective) in a Gram-stained urethral smear or $\geqslant 15$ PMNL per high power field ( $\times 40$ objective) in urine sediment, and negative cultures for $N$ gonorrhoeae; (c) they did not have trichomonal or herpetic infections or intrameatal warts; $(d)$ they had not taken antibacterial drugs for four weeks before enrolment; and $(e)$ they had given informed assent to participate in the study.

Urethral specimens for Gram staining and for culture for $N$ gonorrhoeae were collected with plastic 
loops, and endourethral swabs were used to obtain specimens for chlamydial and ureaplasmal culture. Two consecutive $10 \mathrm{ml}$ urine samples were passed into plastic containers and suspended material allowed to settle for five minutes at room temperature before microscopical examination for PMNL.

After NGU had been diagnosed patients were treated randomly with either tetracycline hydrochloride $500 \mathrm{mg}$ six hourly or minocycline $50 \mathrm{mg}$ twice daily for seven days; those taking tetracycline were advised to avoid milk products and all patients to abstain from sexual intercourse for three weeks. Follow up examinations were performed one, three, and sometimes six weeks after treatment had been completed. Patients were asked about side effects, symptoms, and further sexual intercourse, and at each attendance specimens were collected as above.

Culture for $N$ gonorrhoeae, $C$ trachomatis, and $U$ urealyticum were by standard methods. ${ }^{10}$ Comparison of groups was by $\chi^{2}$ tests with Yates's correction.

\section{Results}

\section{SENSITIVITY STUDIES}

The minimum inhibitory concentrations of tetracycline and minocycline against 12 strains of $C$ trachomatis and $U$ urealyticum are shown in table $I$. Minocycline was more active than tetracycline against $U$ urealyticum, but there was little difference in their activity against $C$ trachomatis.

\section{CLINICAL STUDIES}

A group of 145 men with NGU was studied, of whom 77 patients were treated with tetracycline and 68 with minocycline; their microbiological results before treatment are shown in table II.

\section{SIDE EFFECTS}

Of the 77 men treated with tetracycline, $14(18 \%)$ reported side effects: drowsiness (4), nausea (5), epigastric pain (4), and sore tongue (1). Of the 68 is treated with minocycline, eight $(12 \%)$ reported side $\vec{\circ}$ effects: drowsiness (1), epigastric pain (2), bad taste in mouth (1), flatulence (1), dizziness of less than one $\vec{\omega}$ day's duration (2), and a fixed drug eruption (1).

\section{RESULTS OF TETRACYCLINE TREATMENT}

Tetracycline was given to 77 men with NGU; before treatment $C$ trachomatis was isolated from $31(40 \%)$ and $U$ urealyticum from $28(36 \%)$ of these men (table II). When re-examined one to two weeks after the end of treatment $61(79 \%)$ of the 77 men were free of urethritis (table III). This result was not affected by the presence or absence of $C$ trachomatis or $U \stackrel{\vec{C}}{\frac{C}{Q}}$ urealyticum before treatment. Thus, of the 31 men who were initially chlamydia-positive and of the $46 \%$ who were initially chlamydia-negative, $26(84 \%)$ and $35(76 \%)$ respectively had no urethritis after treatment. These differences were not significant $\left(\chi^{2}=\right.$ $0.291, \mathrm{p}>0.5$ ). Of 28 men initially ureaplasmapositive and of 49 initially ureaplasma-negative, 21 $(75 \%)$ and $39(80 \%)$ respectively showed no urethritis after treatment. These differences were not significant $\left(\chi^{2}=0.076, p>0.5\right)$.

TABLE I Minimum inhibitory concentrations of tetracycline and minocycline against 12 strains of $C$ trachomatis and U urealyticum

\begin{tabular}{|c|c|c|c|c|c|c|c|c|c|}
\hline \multirow[b]{2}{*}{ Antibiotic } & \multicolumn{9}{|c|}{ No of strains with MICs $(\mathrm{mg} / \mathrm{l})$ of: } \\
\hline & 0.015 & 0.03 & 0.06 & $0 \cdot 12$ & $0 \cdot 25$ & $0 \cdot 5$ & $I \cdot 0$ & $2 \cdot 0$ & $>12$ \\
\hline \multicolumn{10}{|c|}{ Chlamydia trachomatis } \\
\hline Tetracycline & 0 & 0 & 10 & 2 & & & & & \\
\hline Minocycline & 1 & 8 & 3 & $\mathbf{0}$ & & & & & \\
\hline \multicolumn{10}{|c|}{ Ureaplasma urealyticum } \\
\hline Minocycline & & & 1 & 9 & 1 & 0 & 0 & 0 & 1 \\
\hline
\end{tabular}

TABLE II Microbiological findings in 145 patients treated for non-gonococcal urethritis

\begin{tabular}{|c|c|c|c|c|}
\hline $\begin{array}{l}\text { Chlamydia } \\
\text { isolation }\end{array}$ & $\begin{array}{l}\text { Ureaplasma } \\
\text { isolation }\end{array}$ & $\begin{array}{l}\text { Total No } \\
\text { of patients }\end{array}$ & $\begin{array}{l}\text { Treated with } \\
\text { tetracycline }\end{array}$ & $\begin{array}{l}\text { Treated with } \\
\text { minocycline }\end{array}$ \\
\hline $\begin{array}{l}\text { Positive } \\
\text { Positive } \\
\text { Negative } \\
\text { Negative }\end{array}$ & $\begin{array}{l}\text { Positive } \\
\text { Negative } \\
\text { Positive } \\
\text { Negative }\end{array}$ & $\begin{array}{l}22 \\
33 \\
38 \\
52\end{array}$ & $\begin{array}{l}13 \\
18 \\
15 \\
31\end{array}$ & $\begin{array}{r}9 \\
15 \\
23 \\
21\end{array}$ \\
\hline Total & & 145 & 77 & 68 \\
\hline
\end{tabular}


TABLE III Clinical response of men with NGU treated with tetracycline or minocycline

\begin{tabular}{|c|c|c|c|c|c|c|}
\hline \multirow[b]{3}{*}{$\begin{array}{l}\text { Drug } \\
\text { given }\end{array}$} & \multirow[b]{3}{*}{$\begin{array}{l}\text { No of weeks } \\
\text { after treatment } \\
\text { finished }\end{array}$} & \multirow[b]{3}{*}{ Total } & \multicolumn{4}{|c|}{ No of patients reattending } \\
\hline & & & \multicolumn{2}{|c|}{ With urethritis } & \multicolumn{2}{|c|}{ Without urethritis } \\
\hline & & & Total & $\begin{array}{l}\text { Admitting } \\
\text { further sexual } \\
\text { intercourse }\end{array}$ & Total & $\begin{array}{l}\text { Admitting } \\
\text { further sexual } \\
\text { intercourse }\end{array}$ \\
\hline $\begin{array}{l}\text { Tetracycline } \\
\text { Tetracycline } \\
\text { Minocycline } \\
\text { Minocycline }\end{array}$ & $\begin{array}{l}1-2 \\
\geqslant 3 \\
1-2 \\
\geqslant 3\end{array}$ & $\begin{array}{l}77 \\
48 \\
68 \\
40\end{array}$ & $\begin{array}{r}16 \\
9 \\
15 \\
4\end{array}$ & $\begin{array}{l}7 \\
9 \\
5 \\
3\end{array}$ & $\begin{array}{l}61 \\
39 \\
53 \\
36\end{array}$ & $\begin{array}{r}10 \\
14 \\
6 \\
17\end{array}$ \\
\hline
\end{tabular}

Isolates of $C$ trachomatis had been obtained from 31 of 77 men with NGU before treatment, but the organisms were not recovered from any of these patients one to two weeks after treatment. Isolates of $U$ urealyticum were obtained from 28 of the 77 men before treatment. It was reisolated from four $(\mathbf{1 4 \%})$ of these $\mathbf{2 8}$ men one to two weeks after treatment and isolated for the first time from a further two men. Of the six men yielding ureaplasmas after treatment, three had persistent urethritis and three no disease.

Re-examination at or after three weeks after treatment of $\mathbf{4 8}$ men who had shown no urethritis one to two weeks after treatment indicated that nine (19\%) then had evidence of urethritis; all admitted to further sexual intercourse. $C$ trachomatis was not recovered from any of the 48 men. $U$ urealyticum was recovered from one man (previously culturenegative) without urethritis. It was not isolated from any of the nine men with urethritis, and the aetiology of their disease could not be determined.

\section{RESULTS OF MINOCYCLINE TREATMENT}

Minocycline was given to 68 men with NGU; before treatment $C$ trachomatis was isolated from $24(35 \%)$ and $U$ urealyticum from $32(47 \%)$ of these men (table II). When re-examined one to two weeks after the end of treatment, $53(78 \%)$ of the 68 men were free of urethritis. This result was not affected by the presence or absence of $C$ trachomatis or $U$ urealyticum before treatment. Thus, of the 24 men who were initially chlamydia-positive and of the 44 who were initially chlamydia-negative, $22(92 \%)$ and $32(73 \%)$ respectively had no urethritis after treatment. These differences were not significant $\left(\chi^{2}\right.$ $=2 \cdot 5,0 \cdot 5>\mathrm{p}>0 \cdot 1)$. Of 32 men initially ureaplasmapositive and of 36 initially ureaplasma-negative, 23 $(72 \%)$ and $30(83 \%)$ respectively showed no urethritis after treatment. These differences were not significant $\left(\chi^{2}=0.713, \mathrm{p}>0.5\right)$.

Isolates of $C$ trachomatis had been obtained from 24 of 68 men with NGU before treatment, but the organisms were not recovered from any of these men one to two weeks after treatment. Isolates of $U$ urealyticum were obtained from 32 of the 68 men before treatment. It was reisolated from four of these $32(12 \cdot 5 \%)$ men one to two weeks after treatment; one showed persistent urethritis but the other three no disease.

In $\mathbf{4 0}$ men who had had no urethritis one to two weeks after treatment, re-examination at or after three weeks after treatment indicated that four $(10 \%)$ then showed evidence of urethritis; three admitted to further sexual intercourse. $C$ trachomatis was not recovered from any of these $\mathbf{4 0}$ men. $U$ urealyticum was recovered from two of the four men with urethritis (both previously culture-negative) but from none of the 36 without urethritis.

\section{Discussion}

The in vitro results (table I) confirm previous reports of the activity of tetracycline and minocycline against $C$ trachomatis and $U$ urealyticum. ${ }^{37}$ The results of the clinical studies were in general consistent with this, but $C$ trachomatis responded more uniformly than $U$ urealyticum. All the men with chlamydiapositive NGU were culture-negative after treatment with either drug and remained so during surveillance for up to six weeks from the completion of treatment. In contrast, $U$ urealyticum was reisolated one to two weeks after treatment from five of 28 men with ureaplasma-positive NGU who were treated with tetracycline and four of 32 men treated with minocycline. Reinfection after early resumption of sexual intercourse is possible (see table III), but as chlamydia were not reisolated treatment failure seems more likely.

About $80 \%$ of men with NGU were free from urethritis one to two weeks after treatment with either antibiotic, and the result was not affected by the microbiological status of the patients before treatment. On re-examination at or after three weeks after treatment urethritis was seen in some patients who had appeared to be cured earlier. This happened after treatment with either drug and did not correlate with isolation or reisolation of $C$ trachomatis or $U$ 
urealyticum. This recurrent disease is clearly associated with the resumption of sexual intercourse, but its cause is uncertain.

In many cases the disappearance of ureaplasmas correlated with cure, but clinical resolution accompanied by persistence of ureaplasmas and persistence of symptoms and signs of infection despite elimination of the organisms were both seen in some patients and cast doubts on the pathogenicity of $U$ urealyticum in the male urethra. Further research into the complex aetiology of NGU will no doubt resolve some of these problems.

Clinically, however, both tetracycline and minocycline in the dosage used gave good results in the treatment of NGU. Side effects were not a problem with the relatively low dose of minocycline which we used and minocycline may give better compliance as its dose schedule is simple and dietary restrictions are unnecessary; its clinical and microbiological effectiveness should be evaluated in women.

\section{References}

1. Oriel JD, Ridgway GL. Genital infections by Chlamydia on trachomatis. London: Edward Arnold, 1982; 41-52.

2. Taylor-Robinson D, McCormack WM. The genital mycoplasmas (first of two parts). $N$ Engl $J$ Med 0 1980,302: 1003-10

3. Bowie WR, Lee CK, Alexander ER. Predictions of efficacy of antimicrobial agents in treatment of infections due to Chlamydia trachomatis. J Infect Dis 1978; 138:655-9.

4. Stimson JB, Hale J, Bowie WR, Holmes KK. Tetracyclineresistant Ureaplasma urealyticum: a cause of persistent nongonococcal urethritis. Ann Int Med 1982;94:192-4.

5. Wood MJ, Farrell W, Kattan S, Williams JD. Activity of minocycline against respiratory pathogens related to blood levels. J Antimicrob Chemother 1975;1:323-31.

6. Chow AW, Patten V, Guze LB. Comparative susceptibility of anaerobic bacteria to minocycline, doxycycline and tetracycline. Antimicrob Agents Chemother 1975; 7:46-9.

7. Spaepen MS, Kundsin RB, Horne HW. Tetracycline-resistant $\mathscr{C}$ T-mycoplasmas (Ureaplasma urealyticum) from patients with a history of reproductive failure. Antimicrob Agents Chemother 1976;9: $1012-8$.

8. Davis JW, Hanna BA. Antimicrobial susceptibility of Ureaplasma urealyticum. J Clin Microbiol 1981;13:320-5.

9. Evans RT, Taylor-Robinson D. The incidence of tetracycline- $\mathrm{G}$ resistant strains of Ureaplasma urealyticum. J Antimicrob $\mathrm{O}$ Chemother 1978; 4:57-63.

10. Stokes J, Ridgway GL. Clinical bacteriology, 5th ed. London: Edward Arnold, 1980 